\begin{tabular}{|l|l|l|}
\hline \multicolumn{2}{|c|}{ PublisherInfo } \\
\hline \hline PublisherName & $:$ & BioMed Central \\
\hline \hline PublisherLocation & $:$ & London \\
\hline \hline PublisherImprintName & $:$ & BioMed Central \\
\hline \hline
\end{tabular}

\title{
BLys expression and function in Lupus
}

\begin{tabular}{|l|l|l||}
\hline \multicolumn{2}{|c|}{ ArticleInfo } \\
\hline \hline ArticleID & $:$ & 83 \\
\hline \hline ArticleDOI & $:$ & $10.1186 /$ ar-2001-68241 \\
\hline \hline ArticleCitationID & $:$ & 68241 \\
\hline \hline ArticleSequenceNumber & $:$ & 40 \\
\hline \hline ArticleCategory & $:$ & Paper Report \\
\hline \hline ArticleFirstPage & $:$ & 1 \\
\hline \hline ArticleLastPage & $:$ & 3 \\
\hline \hline & & RegistrationDate : 2001-7-26 \\
ArticleHistory & $:$ & Received \\
\hline \hline ArticleCopyright & $:$ & Biomed Central Ltd2001-3-8 \\
\hline \hline ArticleGrants & $:$ & \\
\hline \hline ArticleContext & $:$ & 130753311 \\
\hline \hline
\end{tabular}


Sylvie Fournel, Affl

Aff1 CNRS, Strasbourg, France

Keywords

B cell, BLyS, SLE

\section{Context}

B lymphocyte stimulator (BLyS), also called BAFF, TALL-1 and zTNF4, is a newly identified member in the tumor necrosis factor (TNF) family that exhibits a strong costimulatory function for B cell activation in vitro. BLyS-transgenic mice develop severe B cell hyperplasia and autoimmune lupuslike disease. Moreover, in two murine models of human systemic lupus erythematosus (SLE), MRL/Mplpr/lpr and NZB/W F1 mice, increased serum levels of BLyS seem to correlate with autoimmune kidney damage. Knowing that treatment with the soluble BLyS receptor significantly improves the survival of lupus mice, the authors examined the serum level and function of BLyS in the patients with SLE.

\section{Significant findings}

BLyS was increased in sera and plasma of 150 patients of SLE in comparison with 38 normal control patients. Interestingly, BLyS levels in the sera of 44 patients with rheumatoid arthritis (RA) and the synovial fluids of 57 RA patients were also significantly higher than levels in normal sera. In SLE patients, BLyS exerted a costimulatory effect when B cells were activated by anti-IgM antibodies. Finally, the increased level of BLyS in SLE patients was associated with an increased production of anti-dsDNA antibody, which may participate in disease pathogenesis, but was not associated with production of other antinuclear protein antibodies.

\section{Comments}

These results confirm results obtained in lupus-prone mice and provide new clues as to how B cells may contribute to the development of systemic autoimmune disease. Indeed, the high level of BLyS may explain the low activation threshold of B cells in lupus. Moreover, the identification of specific cell 
subsets (eg monocytes, macrophages and dendritic cells) which express BLyS in SLE provide further insight into the pathogenesis of SLE.

\section{Methods}

ELISA, immunoprecipitation, cell proliferation

\section{Additional information}

\section{References}

1. Zang J, Roeschke V, Baker KP, Wang Z, Alarcon GS, Fessler BJ, Bastian H, Kimberly RP, Zhou T: Cutting edge: a role for B lymphocyte stimulator in systemic lupus erythematosus. J Immunol. 2001, 166: 6-10. 